\title{
Isolation and properties of collagen extracted from mixed by-products obtained from different fish species
}

\author{
Aislamiento y propiedades de colágeno extraído de una mezcla de subproductos \\ de diferentes especies de pescado
}

\begin{abstract}
Celia Olivia García-Sifuentes*, Julio Cesar Zamorano-Apodaca, Marcel Martínez-Porchas, Susana Maria ScheurenAcevedo, and Miguel Angel Mazorra-Manzano.

Laboratorio de Bioquímica y Calidad de Productos Pesqueros. Centro de Investigación en Alimentación y Desarrollo A.C. (CIAD), Carretera Gustavo Astiazarán Rosas No. 46. Hermosillo, Sonora, México, Cp 83304. Ph/Fax: +52(662)280-0421, $+52(662) 289-2400$ ext 606
\end{abstract}

\section{ABSTRACT}

Fish by-products consisting of skin, bones, or scales are collagen sources. Acid-soluble collagen (ASC) and pepsin-soluble collagen (PSC) mixed by-products derived from different fish species were extracted and evaluated. The properties evaluated for both collagens were chemical composition, amino acid- and SDS-PAGE- protein profiles, Fourier transform infrared spectroscopy (FTIR), denaturation temperature $\left(T_{\max }\right)$, enthalpy $(\Delta \mathrm{H})$, and solubility. The ASC and PSC registered a protein content of 48.56 and $38.80 \%$ , respectively. From the total amino acids detected, hydroxyproline accounted for $7 \%$ and $6 \%$ for ASC and PSC, respectively. The electrophoretic profile showed the presence of the type I collagen bands ( $\alpha 1, \alpha 2, \beta$, and $\gamma$ ), whereas FTIR spectrum showed the presence of diverse collagen functional groups (Amide A, B, I, II, and III) for both extracted types, and demonstrated that the extraction process did not affect the collagen's triple-helical structure. The $T_{\max }$ of ASC and PSC were 38.27 and $38.07^{\circ} \mathrm{C}$, respectively, whereas $\Delta \mathrm{H}$ were 0.64 and $0.33 \mathrm{~J} \mathrm{~g}^{-1}$. The lowest solubility was registered at $\mathrm{pH} 5$ for ASC and $\mathrm{pH} 9$ for PSC. The caractheristics of the collagen extracted, indicated that a mixture of by-products from different species could be an alternative for their reutilization by the local markets.

Keywords: fish by-products, collagen, isolation, properties, physico-chemical, industrial application.

\section{RESUMEN}

Los subproductos de pescado como pieles, huesos o escamas son fuentes de colágeno. Se extrajo y evaluó el colágeno soluble en ácido (ASC) y soluble en pepsina (PSC) derivados de diferentes especies. Las propiedades evaluadas para ambos colágenos fueron composición química, amino ácidos, perfil electroforético, FTIR, temperatura y entalpía de desnaturalización y, solubilidad. El ASC y PSC registraron 48.6 y $38.8 \%$ de proteína, respectivamente. El ASC y PSC presentaron $7 \%$ y $6 \%$ de hidroxiprolina. El perfil electroforético mostró la presencia de bandas de colágeno tipo I ( $a 1, a 2, \beta$, and $\gamma$ ), el espectro de FTIR mostró los grupos funcionales del colágeno (Amide $A, B, I$, II, and III) y demostró que el proceso de extracción no afectó la estructura de triple hélice. $\mathrm{LaT}_{\text {max }}$ de ASC y PSC fueron 38.27 y $38.07^{\circ} \mathrm{C}$, respectivamente, mientras

*Autor para correspondencia: Celia Olivia García Sifuentes

Correo electrónico: sifuentes@ciad.mx que el $\Delta \mathrm{H}$ fue 0.64 and $0.33 \mathrm{~J} \mathrm{~g}^{-1}$. La solubilidad más baja fue a $\mathrm{pH} 5$ para ASC y a $\mathrm{pH} 9$ para PSC. Ambos tipos de colágeno se extrajeron exitosamente $y$, basados en sus características estructurales, pueden ser una alternativa para la industria de alimentos, biomédica y farmacológica.

Palabras clave: subproductos de pescado, colageno, aislamiento, propiedades.

\section{INTRODUCTION}

Filleting of fish species generates a considerable amount of waste; for example, more than $70 \%$ of solid byproducts are discarded, including skeletons, bones, viscera, heads, tails and skins. Together, these constitute an excellent source of high-quality protein. Particularly skin, bones, and scales, can be used to produce collagen and gelatin (Karayannakidis and Zotos, 2016; Välimaa et al., 2019). Approximately 29 different types of collagen have been identified, each with a different amino acid sequence and biophysical properties. The type I collagen is the most common, made up of three polypeptide chains twisted into a triple-helix. Two of the polypeptides are designed as a 1 when the chain a 1 bonded to another chain $\alpha 1$, form a third chain (a2), which are linked by a hydrogen bond (Yang et al., 2016; Leilei et al., 2017a; Tan and Chang, 2018). The molecular weight of collagen is $300 \mathrm{kDa}$ and approximately $100 \mathrm{kDa}$ for each chain. Most of the collagen obtained from fish by-products is type I and II, having a strong relationship among the molecular weight and the thermal stability. Usually, greater thermal stability occurs at a higher molecular weight. Therefore, the collagen extraction yield and its properties are affected by the extraction method, raw material, pre-treatment, and enzymes used (Pal and Suresh, 2016).

Currently, collagen is extracted from skins and bones of porcine and bovine. However, epidemic events affecting livestock encouraged researchers to endeavor in finding a new collagen source from fish, or fish waste materials, by isolating acid-soluble collagen (ASC), pepsin soluble collagen (PSC), salt soluble collagen (SSC), and ultrasonic collagen (UAC) (Pal et al., 2015; Hamdan and Sarbon, 2019). Several studies have addressed the characterization and extraction of collagen from different fish by-products, such as Thunnus albacares, Carcharhinus albimarginatus, Ctenopharyngodon 
Idella, Ictalurus punctatus, Ictalurus punctatus, Oreochromis niloticus, Gadus macrocephalus, Rana nigromaculata and Ctenopharyngodon idella (Onouma et al., 2014; Elango et al., 2014; Liu et al., 2015a; Yuqing et al., 2017; Wang et al., 2017; Leilei et al., 2017b; Leilei et al., 2017a; Zhang and Duan, 2017; Zhu et al., 2019); however, these focused on specific fish species. Still, there are scarce studies considering a mix of by-products generated after the filleting of different fish species, as happens frequently in differents markets. For instance, more than 3000 tons of by-products produced per year in México can be used to obtain collagen instead of discarding as leftovers (García-Sifuentes et al., 2020). In this sense, finding an alternative for using these mixtures of fish by-products is imperative, generating a potential added value while indirectly contributing to the reduction of waste generation at the local markets or distribution centers, and thus avoiding environmental impacts. Therefore, the objective of this study was to isolate and evaluate ASC and PSC from a mixture of by-products derived from different fish species.

\section{MATERIALS AND METHODS Materials}

As described in a previous study (Zamorano-Apodaca et al., 2020), leftovers of mixed by-products (skins, heads, and skeletons) from various fish species (different sharks, mullet, guitarfish, weakfish, snapper, ray, squid, seabass, and pompano dolphinfish), discarded by the largest distribution market in Mexico, were used for the study. Three different samples were analyzed. All chemicals used in the present work were of analytical grade.

\section{Sample preparation}

Once in the laboratory, the mixture of by-products were homogenized at $4^{\circ} \mathrm{C}, 5$ minutes, and maximum velocity by using a cutter. The three samples obtained were stored at $-20^{\circ} \mathrm{C}$ for less than a week for further analysis, and some sample was also lyophilized.

The pre-treatment of the sample obtained from the mix of different fish species by-products, and the subsequent extraction of acid (ASC) and pepsin soluble collagen (PSC), were conducted using the method described previously (Zamorano-Apodaca et al., 2020).

\section{Obtention of acid (ASC) and pepsin (PSC) soluble collagen} The ASC and PSC extractions were performed at $25^{\circ}$ C. The ASC was extracted with a $0.5 \mathrm{M}$ acetic acid solution for $24 \mathrm{~h}$, as described by Zamorano-Apodaca et al. (2020). The PSC extraction was carried out with $0.01 \%$ pepsin solution $\mathrm{w} / \mathrm{v}$ (dissolved in $0.5 \mathrm{M}$ of acetic acid) for $24 \mathrm{~h}$ and centrifuged at $10,000 \times g$ for 20 minutes, considering the supernatant obtained as the PSC.

The ASC and PSC solutions were ultrafiltrated as described by Zamorano-Apodaca et al. (2020). The concentrated collagen was finally freeze-dried.

\section{Yield and proximate composition}

The yield was obtained based on the raw material wet weight, whereas, the proximate composition of the by-product homogenates, ASC and PSC, were estimated by quantifying protein, lipids, moisture, and ash, according to the AOAC (2000) methods (960.52, 920.39, 950.46, 920.153, respectively). To calculate the crude protein content the 6.25 general Jones conversion factor was used.

\section{Amino acid quantification}

The quantification of amino acids was carried out by HPLC (Vázquez et al., 1997), with modifications described by Zamorano-Apodaca et al. (2020). Six to eight milligrams of both lyophilized collagen types were used for the analysis. The identification of amino acids was carried out by considering the retention time, compared with a standard mixture of amino acids and the results were reported as $\mathrm{mg} / \mathrm{g}$ of sample.

\section{Electrophoretic pattern}

The electrophoretic separation of ASC and PSC was performed according to the method of Laemmli (1970) using $7 \%$ separation gel and $4 \%$ stacking gel. A $1 \mathrm{~g}$ sample of collagen was dissolved in a $5 \%$ SDS and $0.1 \% \beta$-mercaptoethanol solution. Samples were homogenized and heated at $80^{\circ} \mathrm{C}$ for $1 \mathrm{~h}$. The cold sample was centrifuged at 3,000 $\times \mathrm{g}$ for 15 minutes at $25^{\circ} \mathrm{C}$ (Avanti J-26S XPI, Beckman Instruments INC. Palo Alto $(A)$, and $40 \mu \mathrm{g}$ of protein were loaded per path once the protein was quantified (Gornall et al., 1948). To calculate the proteins molecular weight, the bands were stained with coomassie brilliant blue, and a wide-range standard (6.5-200 $\mathrm{kDa}$ ) was used to analyze these bands.

\section{Structural properties}

PSC and ASC functional groups were determined by Fourier Transform Infrared Spectroscopy (FTIR), following the method described by Yousefi et al. (2017). The infrared spectra used ranged from 4000 to $400 \mathrm{~cm}^{-1}$ using a Bruker model IFS 66/S infrared spectrophotometer (Bruker Optics Limited, Coventry, UK), equipped with attenuated total reflectance ATR (SPECAC, Orpington, UK). Freeze-dried ASC and PSC were placed into the ATR and the resulting spectra were analyzed using the OriginPro 8 software (OriginLab Corporation, Northampton, United States).

\section{Temperature and enthalpy of thermal denaturation}

The temperature and enthalpy of thermal denaturation were monitored by following the methodology proposed by Rashidy et al. (2015), and using a DSC7 calorimeter (Perkin Elmer de México, S.A. Monterrey, México). Three mg of ASC and PSC were re-hydrated with $27 \mu \mathrm{L}$ of $0.5 \mathrm{M}$ acetic acid, and the sample was scanned at $5{ }^{\circ} \mathrm{C}$ per minute from 10 to $90^{\circ} \mathrm{C}$ under high atmospheric nitrogen conditions (40 $\mathrm{mL} \mathrm{N} /$ /minute). The initial and maximum transition temperatures $\left(T_{\text {ons' }} T_{\text {max }}\right)$ and the enthalpy $(\Delta \mathrm{H})$ were calculated from the thermogram using the Pirys software (Perkin Elmer de México, S.A.). 


\section{Solubility}

The ASC and PSC solubility was determined following the method described by Matmaroh et al. (2011). Briefly, the ASC and PSC samples were dissolved in $0.5 \mathrm{M}$ acetic acid to a concentration of $3 \mathrm{mg} / \mathrm{mL}$, and the mixtures were stirred at $4^{\circ} \mathrm{C}$ for $3 \mathrm{~h}$. Then, the collagen solution $(3 \mathrm{mg} / \mathrm{mL}$, aliquots of $8 \mathrm{~mL}$ ) was adjusted to $\mathrm{pH} \mathrm{3,5,7,9}$ with $6 \mathrm{~N} \mathrm{NaOH}$ or $6 \mathrm{~N}$ $\mathrm{HCl}$ as required. The volume of the solution was adjusted to $10 \mathrm{~mL}$, stirred at $4^{\circ} \mathrm{C}$ for one $\mathrm{h}$ and centrifuged. Finally, the protein content in the supernatant was determined (Lowry et al., 1951). The relative solubility was calculated by comparing this parameter with that obtained at the $\mathrm{pH}$ giving the highest solubility.

\section{Statistical analyses}

Three different samples were taken (random sampling), the experimental design was a one way analysis of variance (ANOVA) performed by using the NCSS software (NCSS, 2011) and a level of significance of $5 \%$. All the experiments were conducted in triplicates $(n=3)$ for the three samples.

\section{RESULTS AND DISCUSSION}

Yield

Pepsin soluble collagen (PSC) and acid soluble collagen (ASC) were successfully isolated from a mix of by-products obtained from different fish species. The wet-weight basis yield of ASC (4.4\%) was 2-fold higher than PSC (2.2\%), in concordance to Hamdan and Sarbon (2019) and Veeruraj et al. (2015), who reported higher yields for ASC compared to PSC. Both studies explained that the low concentration of acetic acid used $(0.5 \mathrm{M})$ had a significant efficiency, ensuring a complete extraction while maintaining the collagen structure. Likewise, ASC and PSC were isolated from sailfish skin with yields of 5.76 and $2.11 \%$ (wet weight basis), respectively (Tamilmozhi et al., 2013); however, the authors reported the incomplete solubilization of the skin. The type of sample probably influenced the yield obtained in our study since high amounts of non-collagenous proteins may be contained in a mix of by-products from different species. On the other hand, the market where the sample was obtained does not regulate the ratio of each by-product; however, the composition of the mixed by-products is similar throughout the year as reported by Garcia-Sifuentes et al. (2020), therefore, it is assumed that the yield of the collagen is not significantly affected by the sampling period.

Additionally, the extraction time of the collagen was $24 \mathrm{~h}$ instead of 48 , or even $72 \mathrm{~h}$, as reported by other authors (Liu et al., 2015a; Zhu et al., 2019).

Regarding the extraction temperature, Liu et al. (2015a) showed that a complete extraction of ASC was maintained regardless of the extraction temperature $\left(4,10,15,20^{\circ}\right.$ C) at $0.5 \mathrm{M}$ of acetic acid concentration, indicating that the extraction temperature did not affect the extraction yield in our experiment. Liu et al. (2015) did not find structural modifications of $\mathrm{ASC}$ at $20^{\circ} \mathrm{C}$, which is a temperature that could be convenient for practical and industrial applications. Similar results will be shown later in the present study.

Papain was used to remove non-collagenous protein (NCP) and the exposition time was $1 \mathrm{~h}$, at $\mathrm{pH} 7.8-8.0$, and $23^{\circ} \mathrm{C}$. Under these conditions and using an electrophoresis approach, Hong et al. (2019) reported that papain fails to disrupt the collagen structure after one hour of incubation. Still, after 24 hours the collagen structure was disrupted. In this study, the presence of collagen in NCP (data not shown) was not observed through electrophoresis nor amino acid quantification. The effectiveness of the papain enzyme is associated with its activity in the linear structure of the protein, whereas the collagen peptide bonds are not fully accessible to the proteases since the molecule has secondary and tertiary structures, in addition to enzymatic and non-enzymatic cross-linking between fibrils; therefore, hydrolysis would depend directly on the experimental conditions $(\mathrm{pH}$, temperature, time, ion strength, etcetera). Thus, papain is not as effective for hydrolyzing collagen cross-link bonds under these conditions. Collagen hydrolysis with papain can be performed, but temperatures above $65^{\circ} \mathrm{C}$ and $\mathrm{pH}$ from 5 to 7 are required.

\section{Proximate composition}

The proximate composition of the mixed by-products from different fish species, ASC, and PSC are shown in Table 1. The raw homogenate of mixed by-products from various fish species was high in moisture content, coinciding with the value reported by Kosseva et al. (2013). The second essential component shwing high levels was protein, enhancing the relevance of collagen extraction. The lipid content turned out to be a minor component, which is explained based on the lean species sampled and therefore, the collagen yield was not affected by this component. The protein content of ASC was $10 \%$ higher than PSC, while ash and moisture were similar for both collagen types, and no lipids were detected, probably because the raw homogenate had a meager quantity $(1.76 \%)$ that could be removed during the first wash, after the deproteinization process. Protein content reported by Solari and Cordova (2015) was less than $74 \%$, which can be attributed to the modifications in the extraction process (Zamorano-Apodaca et al., 2020). However, collagen recov-

Table 1. The proximate composition (\%) of the mix of by-products homogenate from different fish species, acid soluble collagen (ASC) and pepsin soluble collagen (PSC).

Tabla 1. Comprosición proximal (\%) de la mezcla de subproductos de diferentes especies, colágeno soluble en ácido (ASC) y colágeno soluble en pepsina (PSC).

\begin{tabular}{lcccc}
\hline Sample & Protein & Ash & Moisture & Fat \\
\hline H (\%) & $17.41 \pm 0.07$ & $5.38 \pm 0.07$ & $72.50 \pm 0.21$ & $1.76 \pm 0.08$ \\
ASC (\%) & $48.56 \pm 3.77^{\mathrm{a}}$ & $27.69 \pm 4.01^{\mathrm{a}}$ & $5.59 \pm 0.10^{\mathrm{a}}$ & nd \\
PSC (\%) & $38.80 \pm 6.31^{\mathrm{b}}$ & $27.98 \pm 0.01^{\mathrm{a}}$ & $5.49 \pm 0.17^{\mathrm{a}}$ & nd \\
\hline
\end{tabular}

Different superscript letters between ASC and PSC show significant difference $(P<0.05)$. H: mix of by-products homogenate. nd: not detected. 
ery was not structurally affected by the extraction process, as shown by FTIR and DSC analyses. Though the lyophilized ASC and PSC extract were not utterly pure because both contained high ash levels, the results showed hydroxyproline contents of 7 and $6 \%$, respectively and therefore, the conversion factor to collagen was 14.28 and 16.66 . Finally, when the total nitrogen content of the ASC and PSC was multiplied by the factor, it revealed that the protein recovered in lyophilized ASC and PSC was $100 \%$ collagen.

\section{Amino acid quantification}

The ASC and PSC amino acid composition is shown in Table 2. Differences $(P<0.05)$ among them were observed for all amino acids quantified, except glutamic acid, histidine, serine, histidine, threonine, methionine, and lysine. Then, the major amino acid quantities were detected in the following descending order: glycine, proline, glutamic acid, arginine, alanine, and hydroxyproline for ASC, whereas for PSC were glycine, glutamic acid, arginine, proline, threonine, alanine, aspartic acid, and hydroxyproline. Glycine, proline, and hydroxyproline are the essential amino acids of collagen and its contents showing proportions of $27 \%, 15 \%$, and $7 \%$, respectively for ASC, and $26 \%, 9 \%$, and $6 \%$, respectively for PSC. Hydroxyproline is the most critical amino acid because it is exclusively associated with stromal proteins such as collagen. Glycine was the most abundant amino acid detected, and its quantity is explained because of its detection in every third amino acid residue of the collagen structure. The results

Table 2. Amino acid composition of acid soluble collagen (ASC) and pepsin soluble collagen (PSC).

Tabla 2. Composición de aminoácidos de colágeno soluble en ácido (ASC) y colágeno soluble en pepsina (PSC).

\begin{tabular}{lcc}
\hline Amino acid & PSC $(\mathbf{m g} / \mathbf{g})$ & ASC $(\mathbf{m g} / \mathbf{g})$ \\
\hline Aspartic acid & $38.7 \pm 5.5^{\mathrm{a}}$ & $31.6 \pm 3.1^{\mathrm{b}}$ \\
\hline Glutamic acid & $61.4 \pm 6.8^{\mathrm{a}}$ & $59.1 \pm 4.5^{\mathrm{a}}$ \\
\hline Serine & $15.1 \pm 1.7^{\mathrm{a}}$ & $16.3 \pm 1.8^{\mathrm{a}}$ \\
\hline Histidine & $1.9 \pm 1.1^{\mathrm{a}}$ & $1.3 \pm 0.4^{\mathrm{a}}$ \\
\hline Arginine & $51.8 \pm 7.0^{\mathrm{a}}$ & $57.7 \pm 6.0^{\mathrm{b}}$ \\
\hline Glycine & $143.4 \pm 20.9^{\mathrm{a}}$ & $170.4 \pm 22.1^{\mathrm{b}}$ \\
\hline Threonine & $40.3 \pm 12.4^{\mathrm{a}}$ & $31.6 \pm 6.3^{\mathrm{a}}$ \\
\hline Alanine & $41.1 \pm 4.9^{\mathrm{a}}$ & $50.3 \pm 7.4^{\mathrm{b}}$ \\
\hline Tyrosine & $8.9 \pm 1.8^{\mathrm{a}}$ & $5.4 \pm 1.8^{\mathrm{b}}$ \\
\hline Methionine & $5.2 \pm 1.0^{\mathrm{a}}$ & $5.3 \pm 0.8^{\mathrm{a}}$ \\
\hline Valine & $14.0 \pm 2.1^{\mathrm{a}}$ & $10.5 \pm 2.0^{\mathrm{b}}$ \\
\hline Phenylalanine & $8.4 \pm 2.9^{\mathrm{a}}$ & $4.6 \pm 1.7^{\mathrm{b}}$ \\
\hline Isoleucine & $9.7 \pm 1.2^{\mathrm{a}}$ & $7.4 \pm 1.6^{\mathrm{b}}$ \\
\hline Leucine & $17.8 \pm 1.5^{\mathrm{a}}$ & $15.6 \pm 1.8^{\mathrm{b}}$ \\
\hline Lysine & $23.2 \pm 4.1^{\mathrm{a}}$ & $24.6 \pm 2.9^{\mathrm{a}}$ \\
\hline Proline & $48.4 \pm 14.8^{\mathrm{a}}$ & $94.1 \pm 16.4^{\mathrm{b}}$ \\
\hline Hydroxyproline & $31.5 \pm 7.1^{\mathrm{a}}$ & $43.9 \pm 16.1^{\mathrm{b}}$ \\
\hline
\end{tabular}

All values are mean $\pm S D, n=3$. Different superscript letters between same row show significant difference $(P<0.05)$. obtained from this study were similar to those reported for pigskin and marine fish scales from Japan and Vietnam (Saurida spp., Trachurus japonicus, Mugil cephalis, Cypselurus melanurus, Dentex tumifrons), registering proline proportions of $13.1 \%$ and $10.1 \%$ respectively, $9.8 \%$ and $6.4 \%$ of hydroxyproline, and $32.2 \%$ and $33.8 \%$ of glycine (Thuy et al., 2014; Duconseille et al., 2015).

\section{Electrophoretic pattern}

Although, the protein patterns for ASC was reported in a previous study (Zamorano-Apodaca et al., 2020), the comparison among both ASC and the PSC are shown in Figure 1. A similar pattern was observed for both collagen types, with higher molecular weights for a1 bands (129-139 kDa) than a2 bands (119-126 kDa). The $\beta$ and $\gamma$ bands for both collagen types were $>200 \mathrm{kDa}$. These bands are characteristic properties of collagen because of their a triple helix chains with molecular weights around $100 \mathrm{kDa}$. The $\mathrm{a} 1$ and $\mathrm{a} 2$ chains can be linked together, forming the $\beta$ chain, however, when three $a$ chains $(a 1, a 2)$ are linked together by intermolecular or intramolecular bonds, these from a new arrangement

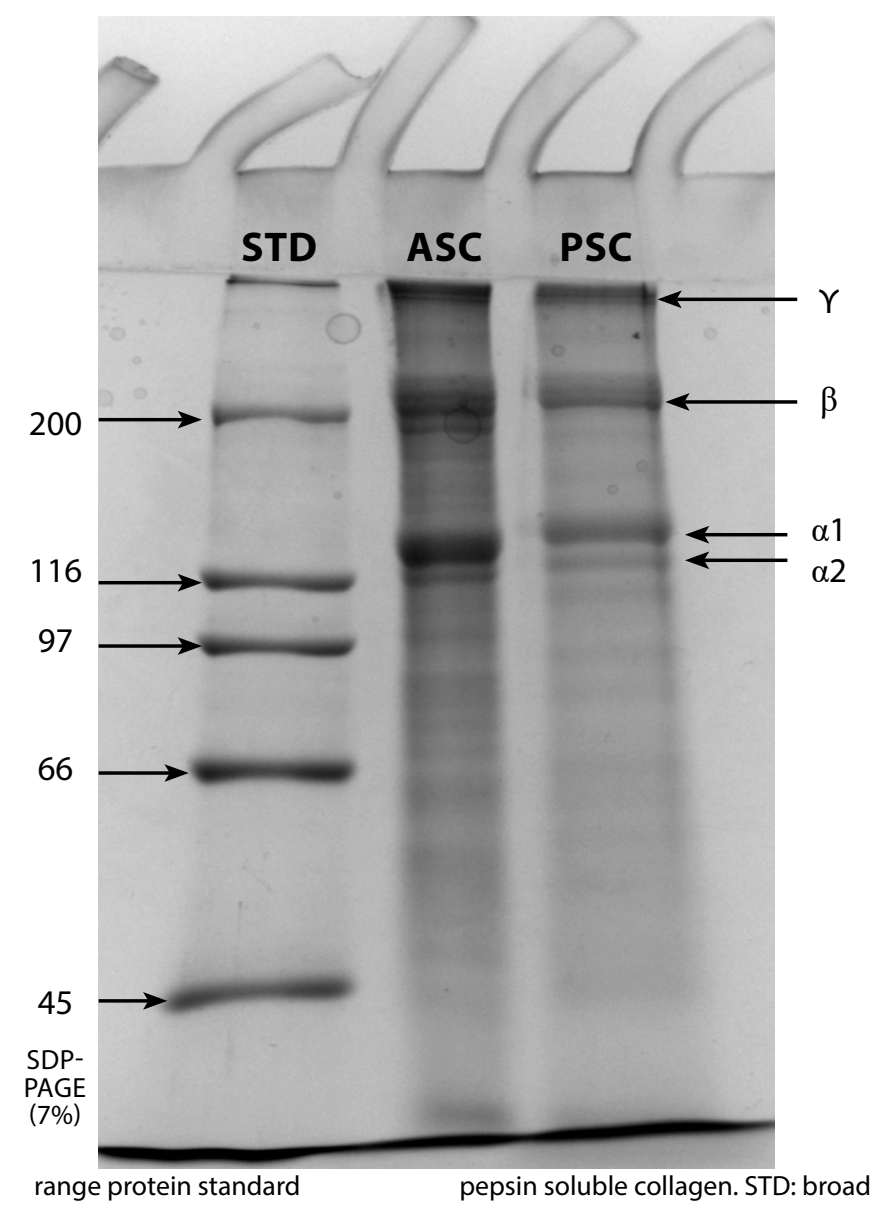

Figure 1. SDS-PAGE (7\%) electrophoretic pattern of acid soluble collagen (ASC) and pepsin soluble collagen (PSC). STD: broad range protein standard.

Figura 1. Patrón electroforético por SDS-PAGE (7\%) de colágeno soluble en ácido (ASC) y colágeno soluble en pepsina (PSC). STD: Estándar de amplio margen. 
which is considered as the $\gamma$ chain (Sun et al., 2017; Yousefi et al., 2017; Slimane and Sadok, 2018). The $\beta$ and $\gamma$-chains observed in both ASC and PSC, indicate the presence of high $M W$ cross-links, but the band intensity of $\beta$-chain and $\alpha$-chain of ASC was more intense than that observed in PSC. This suggests that the acid was able to cleave the telopeptide region, thereby releasing more $a-$ and $\beta$-chains in ASC. Contrary to our results, Ali et al. (2017) reported $\beta$-chain and $\alpha$-chain more intense in PSC.

The most abundant and essential collagen is Type I, because it is a natural macromolecular hydrocolloid used by the food, pharmaceutics, cosmetic, and biomedical industry. This kind of collagen could be obtained from bones, skin, ligaments, tendons, cornea, and scales of fisheries by-products (Jie et al., 2018), as used in the present study.

\section{Structural properties Infrared spectroscopy with Fourier transform, attenua- ted total reflectance (FTIR-ATR)}

As the peak of interest is produced at a specific wavelength and absorbance, the functional group (amide $A$, amide II, amide III) and its vibration mode could be identified.

Figure 2 shows the infrared spectrum of the ASC and PSC obtained from the tested by-products mixture. The spectrum show the presence of the specific functional groups of collagens (Amide A, B, I, II, and III).

The amide A functional group was located at 3293 and $3288 \mathrm{~cm}^{-1}$ for ASC and PSC, respectively, indicating the presence of amino groups $(\mathrm{N}-\mathrm{H})$ involved in the association of hydrogen bonds, and having a strong hydrogen bond into the ASC and PSC. The amide B functional group is associated with the asymmetric stretching vibrations of the $=\mathrm{C}-\mathrm{H}$ and $-\mathrm{NH}^{+3}$ bonds. The ASC and PSC amide functional groups B were detected at $2932 \mathrm{~cm}^{-1}$ and $2933 \mathrm{~cm}^{-1}$, respec-

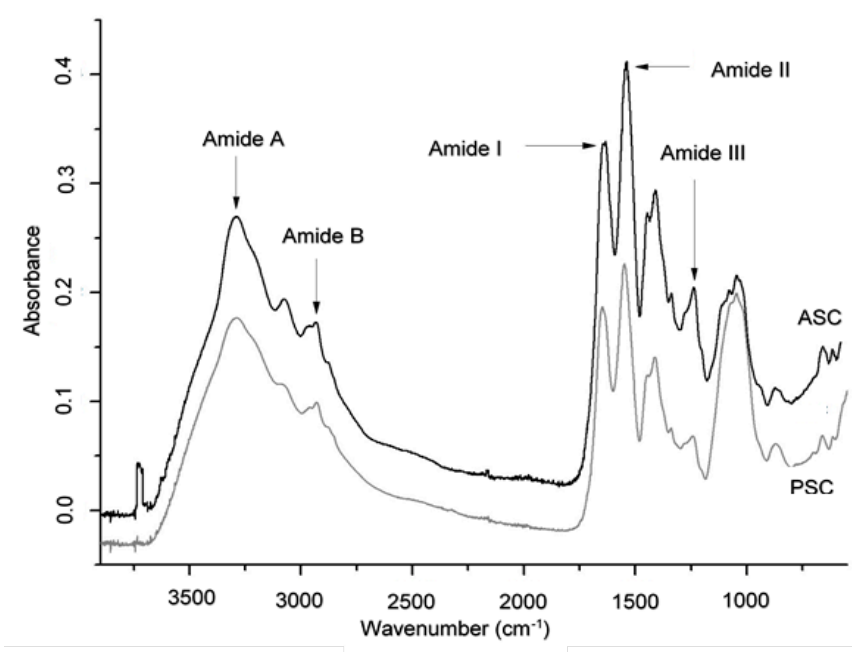

Figure 2. FTIR spectrum molecular identification of acid soluble collagen (ASC) and pepsin soluble collagen (PSC) from mixed by-products of different species.

Figura 2. Espectro de identificación molecular por FTIR de colágeno soluble en ácido (ASC) y colágeno soluble en pepsina (PSC). tively. The amide I functional group is associated with the stretching vibrations of the carbonyl groups $(C=O)$, either in the polypeptide or in the hydrogen bond coupled with a carboxyl group (COO-) (Yousefi et al., 2017; Ahmed et al., 2018). In the ASC and PSC, this functional group was located at 1639 and $1648 \mathrm{~cm}^{-1}$, indicating a good degree of molecular order, supporting the claim that "the lower the wave number of the functional group, the greater the molecular order of the collagen". This observation confirmed that the formation of a hydrogen bond between $\mathrm{N}-\mathrm{H}$ stretch ( $\mathrm{X}$ position) and $\mathrm{C}=\mathrm{O}$ $(G / y)$ of the fourth residue is responsible for the formation of a triple helix.

The amide II functional group is associated with the flexion of the $\mathrm{NH}$ groups coupled with the stretching vibrations of the $\mathrm{CN}$ and $\mathrm{NH}$ groups. In the ASC and PSC samples, the functional group was located at $1541 \mathrm{~cm}^{-1}$ and $1550 \mathrm{~cm}^{-1}$; this indicates that the most of the hydrogen bonds are given by the amino groups (Barth and Zscherp, 2002; Yousefi et al., 2017), and ASC presented more and/or stronger hydrogen bonds than PSC because the amide II peaks were detected at a lower wavelength. This suggests that acid disrupted the non-helical portion of telopeptide regions, resulting in a higher structure order of ASC.

The amide III functional group is associated with the flexion of the $\mathrm{N}-\mathrm{H}$ group from the amide bonds and complex with intermolecular interactions in collagen as $\mathrm{C}-\mathrm{N}$ stretching, $\mathrm{N}-\mathrm{H}$ in plane bending from amide linkages as well as vibrations from $\mathrm{CH}_{2}$ of glycine backbone and proline sidechains (Zhang et al., 2014; Zhang and Duan, 2017). In the ASC and PSC samples, the amide III functional group was located at 1239 and $1240 \mathrm{~cm}^{-1}$, indicating that hydrogen bonds were involved in ASC and PSC.

Additionally, the absorption peaks corresponding to pyrrolidine ring vibration of hydroxyproline and proline for ASC and PSC, were observed at 1450 y $1449 \mathrm{~cm}^{-1}$, respectively. The ratio between amide III and pyrrolidine ring vibration of proline and hydroxyproline of ASC and PSC were $1.17(\sim 1)$ (Plepis et al., 1996; Ahmed et al., 2018), revealing that the ASC and PSC were not denatured during the extraction, and the triple-helical structure was still preserved. The triple helix structure is responsible for the rigidity and strength of the collagen fibers (Matmaroh et al., 2011; Veeruraj et al., 2013). Based on the position of amide A, I and, II bands of ASC that were shifted to lower wavenumber as compared to PSC, it could be inferred that ASC would result in a higher structure order of collagen.

\section{Temperature and enthalpy of thermal denaturation}

No significant differences were detected for the ASC and PSC initial thermal transition $\left(T_{\text {ons }}\right)$ and maximum temperature of thermal denaturation $\left(T_{\max }\right)$, whereas for enthalpy $(\Delta \mathrm{H})$, differences were observed $(\mathrm{P}<0.05) . \mathrm{T}_{\text {ons }}$ for ASC and PSC were $35.09 \pm 0.88^{\circ} \mathrm{C}$ and $35.46 \pm 2.1^{\circ} \mathrm{C}$, respectively, $T_{\text {max }}$ of $38.27 \pm 0.87^{\circ} \mathrm{C}$ and $38.07 \pm 2.09^{\circ} \mathrm{C}$, and $\Delta \mathrm{H} 0.64 \pm 0.21 \mathrm{~J}$ $\mathrm{g}^{-1}$ and $0.33 \pm 0.19 \mathrm{~J} \mathrm{~g}^{-1}$, respectively. Noteworthy, PSC had lower $\Delta \mathrm{H}$ values compared to ASC, which might be due to 
the permanence of the telopeptide region after treatment, resulting in a less compact PSC structure. Consequently, PSC requires less energy for destabilization than ASC. Benjakul et al. (2010) reported that the collagen thermal stability is associated with the pyrrolidine rings and hydrogen bonds of the hydroxyproline hydroxyl group, and in this sense, the amino acids content (20 and $14 \%$ for ASC and PSC, respectively) also influenced the collagen stability.

$\mathrm{T}_{\max }$ values were similar to the reported by Ali et al. (2017), for golden carp (Probarbus jullieni) scales, of ASC $\left(37.67^{\circ} \mathrm{C}\right)$ and PSC $\left(37.83^{\circ} \mathrm{C}\right)$, and higher than the reported for catfish, ASC $\left(36.12^{\circ} \mathrm{C}\right)$ and PSC $\left(35.57^{\circ} \mathrm{C}\right)$ by Tan and Chang (2018). Coinciding with our results, these authors also showed less $\triangle H$ for PSC.

\section{Effect of pH on Solubility}

ASC and PSC relative solubility results are shown in Figure 3. Overall, the PSC showed a higher solubility $(P<$ $0.05)$ than ASC. The PSC relative solubility ranged from 62.8 to $100 \%$, while ASC from 62.2 to $99 \%$. As expected, both PSC and ASC showed the highest solubility at $\mathrm{pH} 3$, whereas the lowest solubility was detected at $\mathrm{pH}$ 9. However, although a sharp decrease in solubility can be seen at pH 5 for PSC, probably due to the pepsin effect, its lowest solubility was at $\mathrm{pH}$ 9. Our results were similar to those reported for ASC and PSC obtained from spotted golden goatfish scales (Matmaroh et al., 2011), carp (Catla) scales (Pal and Suresh, 2017), and channel catfish skin (Tan and Chang, 2018). These authors observed the highest solubility under acidic conditions $(\mathrm{pH}$ 2-5), with a sharp decrease at $\mathrm{pH} 5$. However, the solubility increases at alkaline $\mathrm{pH}$ (11) as reported for the spotted golden goatfish scales PSC (Matmaroh et al., 2011). The ASC and PSC highest solubility at acidic $\mathrm{pH}$ could be associated with the discrepancy between $\mathrm{pH}$ and the isoelectric point. The protein net charge was different to zero, then, the repulsion forces between the collagen chain molecules increased, resulting in better solubilization. In contrast, when the $\mathrm{pH}$ is

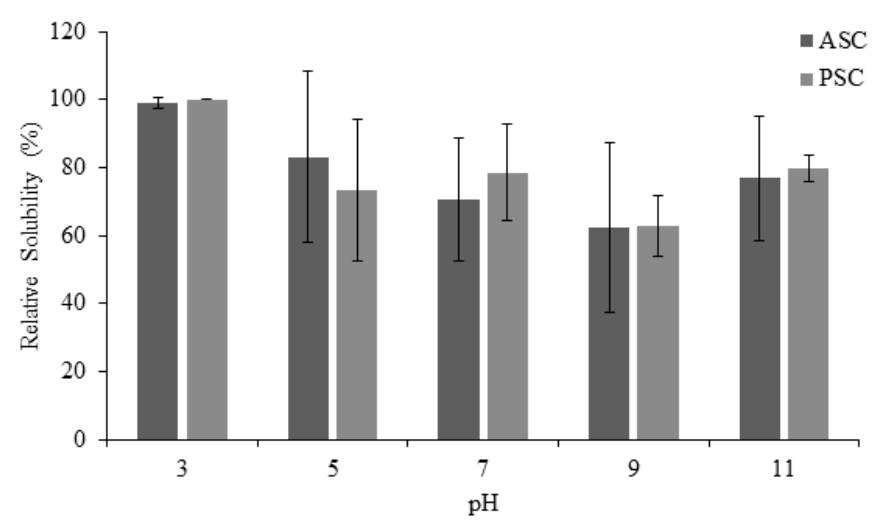

Figure 3. Relative solubility (\%) of acid soluble collagen (ASC) and pepsin soluble collagen (PSP) from mixed by-products of different species at different $\mathrm{pH}$. All the values are mean \pm standard deviation $(n=3)$. Figura 3. Solubilidad relativa (\%) de colágeno soluble en ácido (ASC) y colágeno soluble en pepsina (PSC) derivados de una mezcla de subproductos de diferentes especies de pescado a diferentes $\mathrm{pH}$. Los valores corresponden a la media \pm desviación estándar $(n=3)$. equal or close to the isoelectric point, the total net charge of the protein molecules approaches to zero, and the protein precipitation and aggregation occurs.

The results of our study revealed that the mixed byproducts from different fish species represent a rich source of collagen with desirable physicochemical characteristics. At the same time, the extraction process is technically feasible, considering that no abrupt denaturation of the collagen structure happened.

\section{CONCLUSION}

Acid soluble collagen (ASC) and pepsin soluble collagen (PSC) obtained from mixed by-products from different fish species were successfully extracted. The yield, protein, and hydroxyproline contents of ASC were higher than PSC. However, both were identified as type I collagen, and the particular functional groups of collagens were observed. No denaturation of collagen was detected, demonstrating that the extraction process did not affect the collagen's structure. The PSC solubility was better than ASC, and the $\triangle H$ was lower. Therefore, PSC is probably more functional than ASC probably due to a less compact structure. One of the novel aspects of this work is the fact of employing a mixture of different species by-products, and in this sense, all these results could be used as a basis for crafting strategies to assist the reutilization of waste and by-products from the local markets or big distribution centers. Therefore, both extracted collagens could be an alternative for the food, pharmacological, and biomedical industries.

\section{ACKNOWLEDGEMENT}

The authors thank FONSEC-SEP-CONACYT for the project support.

\section{REFERENCES}

Ahmed, R., Tilahun, A.G., Cho, J., Chun, B. 2018. Application of bacterial collagenolytic proteases for the extraction of type I collagen from the skin of bigeye tuna (Thunnus obesus). LWT- Food Science and Technology. 89: 44-51.

Ali, M.A.M., Benjakul, S., Kishimura, H. 2017. Molecular characteristics of acid and pepsin soluble collagens from the scales of golden carp (Probarbus jullieni). Emirates Journal of Food and Agriculture. 29(6): 450-457.

Barth, A., Zscherp, C. 2002. What vibrations tell about proteins. Quarterly Reviews of Biophysics. 35(4): 369-430.

Benjakul, S., Thiansilakul, Y., Visessanguan, W., Roytrakul, S., Kishimura, H., Prodpran T., Meesane, J. 2010. Extraction and characterization of pepsin-solubilized collagens from the skin of bigeye snapper (Priacanthus tayenus and Priacanthus macracanthus). Journal of the Science of Food and Agriculture. 90(1): 132-138.

Chi, C.F., Cao, Z.H., Wang, B., Hu, F.Y., Li, Z.R., Zhang, R. 2014. Antioxidant and Functional Properties of Collagen Hydrolysates from Spanish Mackerel Skin as Influenced by Average Molecular Weight. Molecules. 19(8): 11211-11230.

Duconseille, A., Astruc, T., Quintana, N., Meersman, F. 2015. Gelatin structure and composition linked to hard capsule dissolution: A review. Food Hydrocolloids. 43: 360-372. 
Elango, J., Wua, W., Wang, N., He, L., Bin, B. 2014. Isolation, purification and characterization of pepsin soluble collagen isolated from silvertip shark (Carcharhinus albimarginatus) skeletal and head bone. Process Biochemistry 49: 1764-1777.

García-Sifuentes, C.O., Scheuren-Acevedo, S.M., ZamoranoApodaca, J.C. 2020. Exploring different by-products considered as residues by the fishery industry in México. Biotecnia. XXII(2): 61-69.

Hamdan, F.S., Sarbon, N.M. 2019. Isolation and characterization of collagen from fringescale sardinella (Sardinella fimbriata) waste materials. International Food Research Journal. 26(1): 133-140.

Hong, H., Fan, H., Chalamaiah, M., Wu, J. 2019. Preparation of low-molecular-weight, collagen hydrolysates (peptides): Current progress, challenges, and future perspectives. Food chemistry. 30(15): 125222.

Jie, L., Wang, M., Qiao, Y., Tian, Y., Liu, J., Qin, S., Wu, W. 2018. Extraction and characterization of type I collagen from skin of tilapia (Oreochromis niloticus) and its potential application in biomedical scaffold material for tissue engineering. Process Biochemistry. 74: 153-163.

Karayannakidis, D.P., Zotos, A. 2016. Fish Processing By-Products as a Potential Source of Gelatin: A Review. Journal of Aquatic Food Product Technology. 25(1): 65-92.

Kosseva, M.R. 2013. Sources, Characterization, and Composition of Food Industry Wastes. In: Food Industry Wastes. R.M Kosseva y C. Webb (Ed.), pp 37-60. Elsevier Inc. USA.

Leilei, S., Bafang, L., Wenkui, S., Leilei, S., Hu, H. $2017 \mathrm{~b}$. Characterization of Pacific cod (Gadus macrocephalus) skin collagen and fabrication of collagen sponge as a good biocompatible biomedical material. Process Biochemistry. 63: 229-235.

Leilei, S., Hu, H., Bafang, L., Zhang, Y. 2017a. Characterization of acid- and pepsin-soluble collagen extracted from the skin of Nile tilapia (Oreochromis niloticus). International Journal of Biological Macromolecules. 99: 8-14.

Liu, D., Wei, G., Li, T., Hu, J., Lu, N., Regenstein, J.M., Zhou, P. 2015a. Effects of alkaline pre-treatments and acid extraction conditions on the acid-soluble collagen from grass carp (Ctenopharyngodon idella) skin. Food Chemistry. 172: 836843.

Liu, D., Zhang, X., Li, T., Yang, H., Zhang, H., Regenstein, J.M., Zhou, P. 2015a. Extraction and characterization of acid-and pepsin-soluble collagens from the scales, skins and swimbladders of grass carp (Ctenopharyngodon idella). Food Bioscience. 9: 68-74.

Matmaroh, K., Benjakul, S., Prodpran, T., Encarnacion, A., Kishimura, H. 2011. Characteristics of acid soluble collagen and pepsin soluble collagen from scale of spotted golden goatfish (Parupeneus heptacanthus). Food Chemistry. 129(3): 1179-1186.

Nagai, T., Suzuki, N. 2000. Isolation of collagen from fish waste material-skin, bone and fins. Food Chemistry. 68(3): 277-281.

Onouma, K., Soottawat, B., Thammarat, K., Hideki, K. 2014. Characteristics of collagens from the swim bladders of yellowfin tuna (Thunnus albacares). Food Chemistry. 155: 264-270.

Pal, G.K., Suresh, P.V. 2016. Sustainable valorization of seafood by-products: Recovery of collagen and development of collagen-based novel functional food ingredients. Innovative Food Science and Emerging Technologies. 37: 201-215.
Pal, G.K., Suresh, P.V. 2017. Comparative assessment of physicochemical characteristics and fibril formation capacity of thermostable carp scales collagen. Materials Science and Engineering. 70(1): 32-40.

Pal, G.K., Nidheesh, T., Suresh, P.V. 2015. Comparative study on characteristics and in vitro fibril formation ability of acid and pepsin soluble collagen from the skin of catla (Catla catla) and rohu (Labeo rohita). Food Research International. 76(3): 804-812.

Plepis, A.M.D.G., Goissis, G., Das-Gupta D.K. 1996. Dielectric and Pyroelectric Characterization of Anionic and Native Collagen. Polymer Engineering \& Science. 36(24): 2932-2938.

Rashidy, A.A., Ahmed, G., Abd, E.H.G., Abu, H., Shaymaa, I., Habib., Badr, N.A., Badr, A. 2015. Chemical and biological evaluation of Egyptian Nile Tilapia (Oreochromis niloticus) fish scale collagen. International Journal of Biological Macromolecules. 79: 618-626.

Serrano, G., Velásquez, L. 2011. Estandarización de un proceso de extracción de colágeno a partir de los residuos de fileteo de tilapia (Oreochromis sp) y cachama (Piaractus brachypomus). Tesis de Maestría. Universidad Nacional de Colombia.

Slimane, E.B., Sadok, S. 2018. Collagen from cartilaginous fish by-products for a potential application in bioactive film composite. Marine Drugs. 16(6): 211.

Solari, A., Cordova, J.S. 2015. Extracción de Colágeno proveniente de residuos del Procesamiento de (Engraulis ringes) "Anchoveta". Ciencia e Investigación. 18(2): 65-68.

Sun, L., Hou, H., Li, B., Zhang, Y. 2017. Characterization of acidand pepsin-soluble collagen extracted from the skin of Nile tilapia (Oreochromis niloticus). International Journal of Biological Macromolecules. 99: 8-14.

Tamilmozhi, S., Veeruraj, A., Arumugam, M. 2015. Isolation and characterization of acid and pepsin-solubilized collagen from the skin of sailfish (Istiophorus platypterus). Food Research International. 54(2): 1499-505.

Tan, Y., Chang, S.K.C. 2018. Isolation and characterization of collagen extracted from channel catfish (Ictalurus punctatus) skin. Food Chemistry. 242(1): 147-155.

Thuy, M.L.T., Okazaki E., Osako, K. 2014. Isolation and characterization of acid-soluble collagen from the scales of marine fishes from Japan and Vietnam. Food Chemistry. 149: 264-270.

Välimaa, A.L., Mäkinen, S., Mattila, P., Marnila, P., Pihlanto, A., Mäki, M., Hiidenhovi, J. 2019. Fish and fish side streams are valuable sources of high-value components. Food Quality and Safety. 3(4):209-226.

Vázquez, O., Caire, F.A., Higuera, C.G., Hernández, W.G. 1997. High performance liquid chromatographic determination of free amino acids in Shrimp. Journal Liquid Chromatography. 18(10): 2059-2068.

Veeruraj, A., Arumugam, M., Balasubramanian, T. 2013. Isolation and characterization of thermostable collagen from the marine eel-fish (Evenchelys macrura). Process Biochemistry. 48: 1592-1602.

Veeruraj, A., Arumugam, M., Ajithkumar, T., Balasubramanian, T. 2015. Isolation and characterization of collagen from the outer skin of squid (Doryteuthis singhalensis). Food Hydrocolloids. 43: 708-716.

Wang, J., Pei, X., Liu, H., Zhou, D. 2017. Extraction and characterization of acid-soluble and pepsin-soluble collagen from skin of loach (Misgurnus anguillicaudatus). International Journal of Biological Macromolecules. 106: 544-550.

Volumen XXIII, Número 3 
Yang, Y., Li, C., Song, W., Wang, W., Qian, G. 2016. Purification, optimization and physicochemical properties of collagen from soft-shelled turtle calipash. International Journal of Biological Macromolecules. 89: 344-352.

Yousefi, M., Ariffin, F., Huda, N. 2017. An alternative source of type I collagen based on by-product with higher thermal stability. Food Hydrocolloids. 63: 372-382.

Yuqing, T., Sam, K. C., Chang. 2017. Isolation and characterization of collagen extracted from channel catfish (Ictalurus punctatus) skin. Food Chemistry. 242: 147-155.

Zamonrano-Apodaca, J.C., Garcia-Sifuentes, C.O., CarvajalMillán, E., Vallejo-Galland, B., Scheuren-Acevedo, S.M., LugoSánchez, M.E. 2020. Biological and funnctional properties of peptide fractions obtained from collagen hydrolysate derived from mixed by-products of different fish species. Food Chemistry. 331: 127350.
Zhang, J., Duan, R. 2017. Characterization of acid-soluble and pepsin-solubilized collagen from frog (Rana nigromaculata) skin. International Journal of Biological Macromolecules. 101: 638-642.

Zhang, J., Duan, R., Huang, L., Song, Y., Regenstein, J.M. 2014. Characterization of acid-soluble and pepsin-solubilized collagen from jellyfish (Cyanea nozakii Kishinouye). Food Chemistry. 150: 22-26.

Zhu, S., Yuan, Q., Yang, M., You, J., Yin, T., Gu, Z., Hu, Y., Xiong, S. 2019. A quantitative comparable study on multi-hierarchy conformation of acid and pepsin-solubilized collagens from the skin of grass carp (Ctenopharyngodon idella). Materials science and engineering. 96: 446-457. 